\title{
FORUM
}

\section{A New Paradigm for Implementing Ecologically - Based Participatory IPM in a Global Context: The IPM CRSP Model}

\author{
E.A. HEINRICHS \\ IPM CRSP, Virginia Tech University, Blacksburg, VA 24060-0334, USA
}

Neotropical Entomology 34(2):143-153 (2005)

Um Novo Paradigma Para Implementar MIP Ecológico e Participativo em um Contexto Global: O Modelo do IPM CRSP

RESUMO - O Manejo Integrado de Pragas (MIP) é um componente essencial no desenvolvimento de agroecossistemas sustentáveis. O Programa Colaborativo de Suporte a Pesquisa em Manejo Integrado de Pragas (IPM CRSP) é financiado pela USAID, que constitui um consórcio de universidades americanas colaborando com programas nacionais de países parceiros e seus apoiadores para promover o MIP globalmente. É baseado no Manejo Integrado de Pragas Participativo (PIPM), processo que visa minimizar: perdas agrícolas devido a pragas, danos a ecossistemas naturais incluindo perda da biodiversidade, poluição e contaminação dos alimentos e água. O modelo participativo IPM CRSP é baseado em trabalho em rede, criando interações entre instituições e o setor privado, desenvolvendo e transferindo pesquisa e tecnologia. O IPM CRSP que se inicia em 2005 será baseado na experiência do IPM CRSP anterior (1992-2004). Seu objetivo é implementar um manejo integrado de pragas participativo com bases ecológicas (EP-IPM) com a estratégia concebida para difundir a capacitação e conhecimento em MIP. Participação ampla e comunicação são componentes críticos da estratégia, juntamente com um processo competitivo e um plano de gerenciamento concebido para garantir pesquisa de alta qualidade e que se justifique. O programa é aberto para as universidades americanas, as quais devem procurar parceiros nos países envolvidos através dos programas nacionais e apoiadores locais no desenvolvimento de Centros Regionais em MIP envolvidos em cinco temas globais, incluindo: espécies invasoras, viroses transmitidas por insetos, laboratórios regionais de diagnósticos, tecnologia de informação e banco de dados, e avaliação de impactos.

PALAVRAS-CHAVE: MIP global, desenvolvimento de tecnologia, aceitação do MIP, trabalho em rede

ABSTRACT - Integrated Pest Management (IPM) is a key component in the development of sustainable agro ecosystems. The Integrated Pest Management Collaborative Research Support Program (IPM CRSP) is a USAID funded project that is a consortium of U.S. universities working with host country national programs and other stakeholders to promote IPM globally. The IPM CRSP model is based on a Participatory Integrated Pest Management (PIPM) process that has as its goals to help reduce: agricultural losses due to pests, damage to natural eco-systems including loss of biodiversity, and pollution and contamination of food and water supplies. The IPM CRSP participatory model is based on networking, institution building, private sector interaction, research-technology development and technology transfer. The new IPM CRSP beginning in 2005 will build on the experience of the previous IPM CRSP (1992-2004). The technical approach of the New IPM CRSP is to implement an ecologically-based, participatory IPM (EP-IPM) program with a carefully-conceived strategy for local, national, regional, and global diffusion of IPM capacity and knowledge. Broad participation and communication are critical components of the strategy, along with a competitive process and a management plan designed to ensure high quality research and accountability. The approach is based on a competitive process open to U.S. universities who are expected to partner with host country national programs and other stakeholders in the development of Regional IPM Centers and on five Global IPM Themes including invasive species, insect transmitted viruses, regional diagnostic laboratories, information technologies and databases, and impact assessment.

KEY WORDS: Global IPM, technology development, IPM adoption, networking 
Globally, there is a desperate need to develop sustainable agricultural systems. Integrated Pest Management (IPM) technology development and transfer is a major component in sustainable agricultural systems. In spite of the progress made in the development and transfer of IPM technology the need for IPM strategies for the world's farmers continues. Pests (insects, diseases, weeds, vertebrates) respect no borders and spread through plant and animal migration, wind, water, and by human activity, including trade in plant and animal products. Concerns over bio-security and invasive species are global issues that require IPM attention in both developed and developing countries. The last 15 years have witnessed an increase in IPM research and capacity building around the world, supported by USAID and other bi-lateral donors, FAO, national governments, non-governmental organizations, international agricultural research centers, universities, and other organizations. Much has been learned, both about IPM tactics and about approaches to IPM research, diffusion, and building institutional capacity. This paper reports on the lessons learned and the impact of the first phase of the IPM Collaborative Research Support Program (CRSP) (19922004) and on how the new IPM CRSP (2005-2009) will build on lessons learned in the first phase to accelerate production and adoption of IPM knowledge on a global basis.

The IPM CRSP is a (United Sates Agency for International Development) USAID funded project that is a consortium of U.S. universities working with host country national programs and other stakeholders to promote IPM globally. The program is coordinated and managed by Virginia Tech University, Blacksburg, Virginia, USA. The overall purpose of the IPM CRSP is to develop and implement a replicable approach to IPM that will help reduce: agricultural losses due to pests, damage to natural eco-systems including loss of biodiversity, and pollution and contamination of food and water supplies.

The IPM CRSP, in its first phase, developed and helped to institutionalize IPM programs at several sites around the world, resulting in impacts on agricultural productivity and profitability, consumer health, and environmental quality. It helped to diagnose pest problems, develop and disseminate IPM strategies, and train IPM professionals. For example, IPM CRSP research identified key pests in Uganda (coffee wilt pathogen), Philippines (onion root knot nematode), Mali and Bangladesh (tomato leaf curl geminiviruses), the Caribbean (pepper gall midge), and Central America (snowpea leafminer), to name just a few. The proper identification of the snowpea leaf miner led to the lifting of the US quarantine of Guatemalan snowpeas for export. This IPM CRSP intervention led to increased trade and improved farm level pest management practices. Pesticide applications were reduced, insect and disease populations decreased, and yields rose (Fig. 1).

Country programs were established at sites in South and Southeast Asia, East and West Africa, Latin America and the Caribbean, and Eastern Europe. The adoption of IPM

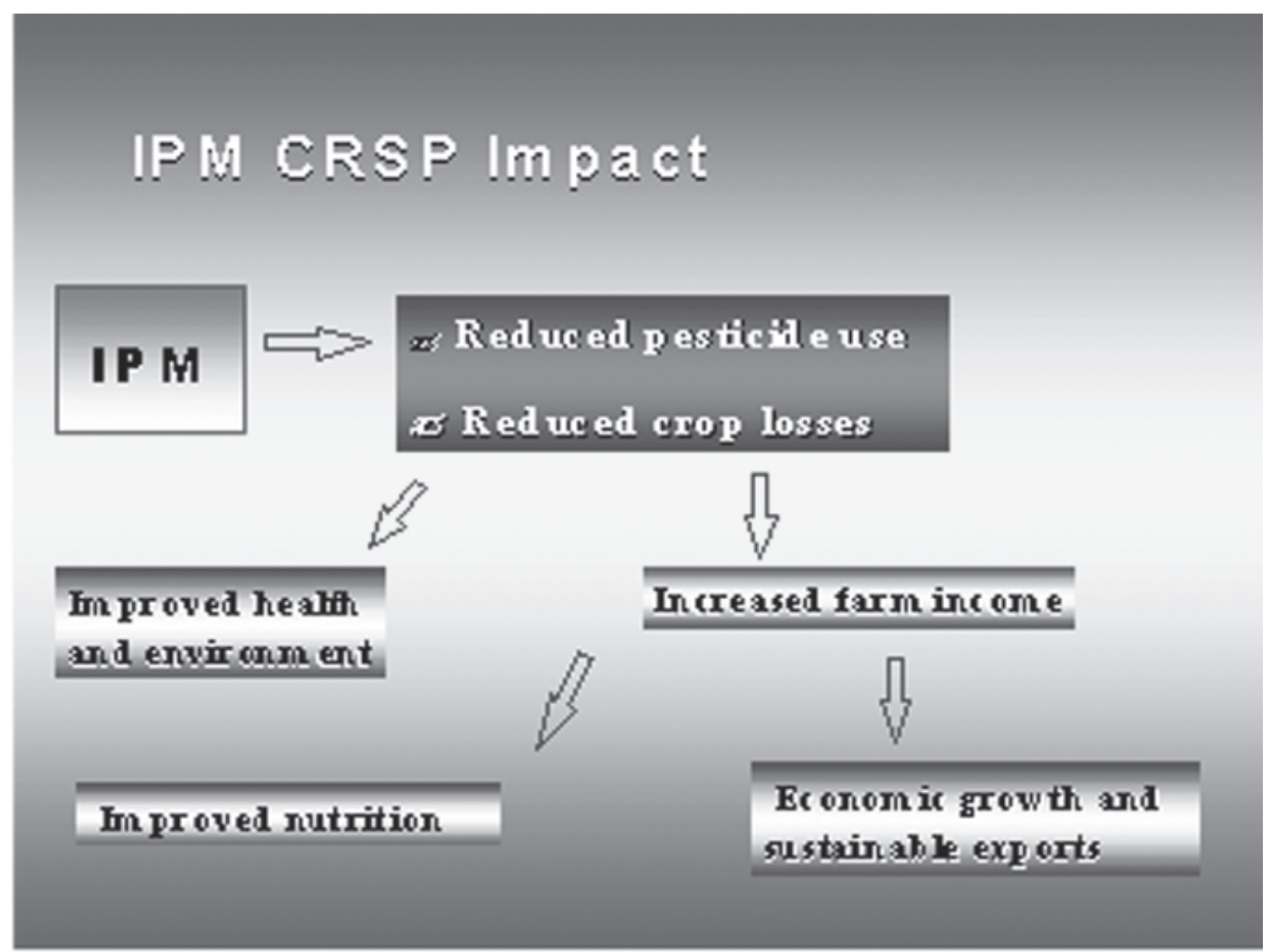

Figure 1. IPM CRSP goals and impact. 
strategies developed through the CRSP increased the profits of farmers in targeted regions. Some of the crops involved were eggplants, onions, cabbage, snowpeas, green beans, olives, potatoes, and sorghum. Profits have increased from 15 to over 200 percent, averaging around 50 percent on the target crops. These farm-level profit increases have led to market-level economic benefits as well, poverty reduction, and environmental improvements.

Institutional impacts of the IPM CRSP were also substantial. Seventy-five students received training at the MS and PhD levels in: Agricultural Economics, Plant Pathology, Entomology, Weed Science, Nematology, Rural Sociology, and related fields. Eighty percent of the students were from host countries and the rest from the United States. Many more received short-term training or undergraduate education.

However the progress as been locally limited and has not reached many of the world's farmers. A growth in IPM programs has occurred in selected Asian countries such as Indonesia, the Philippines, Vietnam, and China, but adoption of IPM remains slow in most of the developing world. The International Agricultural Research Centers (IARCs), the Food and Agricultural Organization (FAO) of the UN, the U.S. Agency for International Development (USAID), CARE, and other organizations have collaborated with scientists and extension workers in developing countries to encourage the development and deployment of IPM systems. Adoption is limited, however, due to technical, institutional, social, cultural, economic, educational/informational, and policy constraints. Future expansion of IPM in developing countries will depend on success in reducing each of these constraints.

The IPM model employed in phase I of the IPM CRSP included: participatory IPM, networking, institution building, private sector involvement, research - technology development, and technology transfer.

\section{Participatory Integrated Pest Management (PIPM) Process}

The goal of PIPM is to increase incomes for the whole population while reducing health and environmental risks associated with pest management. Achieving this goal requires good science, farmer involvement, and recognition of the myriad factors that influence farmer decision-making.

The development and promotion of IPM is dependent on both, technology development and on changing attitudes of farmers, scientists, extension workers, government officials, bankers, industry, NGOs and consumers. IPM requires a common understanding among diverse stakeholder groups of the need for both productivity improvements and for attention to health and environmental concerns. This points out the need for a "participatory approach" to IPM research. Participation plays a major role in networking, private sector interaction, institution building, research-technology development, technology transfer, regionalization/globalization of IPM, change in government policy and recognition of the importance of

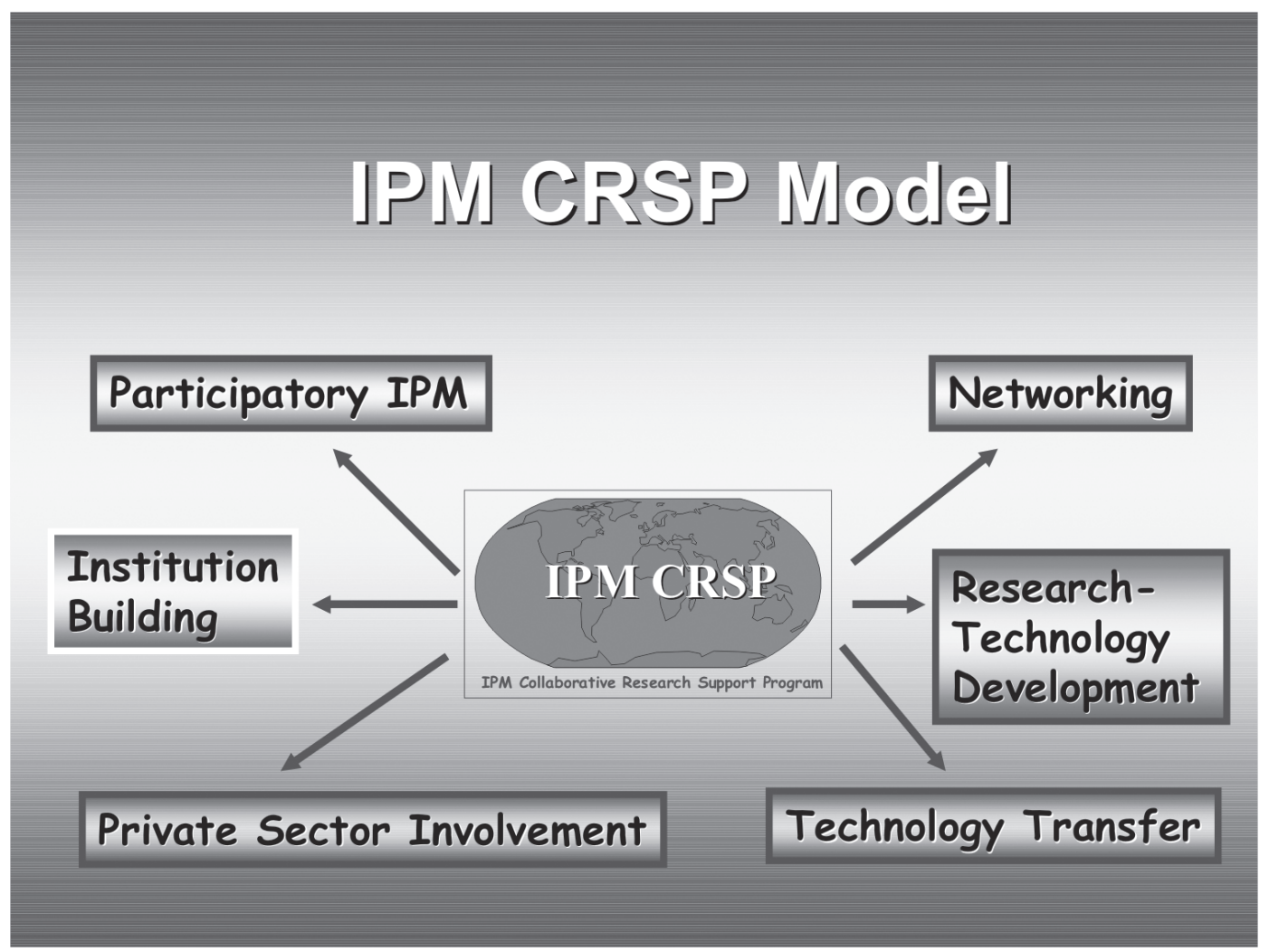

Figure 2. IPM CRSP activities. 
social and gender issues (Fig. 2).

The successful development of IPM programs requires an understanding of agricultural systems and all of the stakeholders involved in the chain from the producer to the consumer. Successful IPM programs require interactions among scientists, public and private extension, farmers, and policy makers. The process of participation is the most important contribution to IPM program development. How do we measure the success of a participatory approach in IPM CRSP programs? The major measurement is, "does it lead to the development of IPM technologies that change behavior and meet the production needs of small scale farmers?" The participatory approach is based on the cooperation and participation of all stakeholders.

The IPM CRSP experience has shown that a successful participatory IPM exercise: provides a solid scientific base for the research program; identifies possible solutions to pest problems; facilitates the spread of IPM strategies; identifies suitable sites for experimental work; and correctly determines the taxonomic status of pests and their natural enemies. The guiding principles of the PIPM process include the following: Farmers and scientists both participate so that they can learn from each other; the IPM research program is multidisciplinary and includes social scientists as well as biological scientists (fundamental and applied); participation extends to the output and input marketing sectors as well as regulatory and other government institutions; appropriate linkages are made to sources of knowledge external to the country; diffusion of IPM knowledge to producers involves all relevant channels in the public and private sectors; multiple methods for IPM diffusion are utilized as appropriate given the nature of the IPM information, time and resources available, and characteristics of recipients; and IPM research is institutionalized in existing organizations in a way that it is sustainable over time.

Participatory IPM is a process that builds on fundamental information about the pests and their environment; identifies solutions to pest problems for specific crops; and facilitates the spread of IPM management strategies. It accomplishes these tasks by involving the appropriate people at each stage in the process so there is no disconnect among the stages. Therefore it begins by identifying the relevant collaborators and other stakeholders (Fig. 3). These people help determine possible sites for experimental work, specific commodity focus, and other aspects that define the broad parameters of the program focus. The initial group of collaborators and stakeholders may include scientists, public and private extension workers including representatives of nongovernmental organizations (NGOs), farmers, representatives from farm organizations, local leaders, public officials, and others.

Site selection is critical since on-farm experimental work requires representative areas and locations where the logistics allow scientists to regularly visit the field. Scientific collaborators are chosen to represent an appropriate disciplinary mix, and typically might include expertise in entomology, plant pathology, weed science, nematology, economics, and sociology/gender analysis. Farmer collaborators are chosen based on interest in working with scientists on their farms. It can work well to collaborate with farmers who are members of a cooperative or other group due to the additional feed back that may be obtained from neighboring farmers, and the increased capacity to spread information. Other stakeholders often include consumers, government officials, NGO representatives, marketing agents and lenders.

The baseline survey may include regions beyond the local research sites in areas where the same crop/pest complex is known to be prevalent. A survey of perhaps 300-400 farmers serves to identify farmers' pest perceptions, pest management practices and decision-making processes, basic socioeconomic characteristics, and other information. It provides a baseline against which evaluation can occur down the road.

A participatory appraisal (PA), which uses a lessstructured information gathering techniques than a baseline survey, complements the survey because it allows for following up on issues that need clarifying (Litsinger et al. 1995). The PA process begins with a brief training session for scientists on PA methods, just prior to going into the field. The PA takes one to two weeks for a typical IPM site and helps to build relationships among collaborators on the project as well assist with research priority-setting. A fourth, key information gathering activity is basic identification and field monitoring of pests and beneficial organisms that may require a few years. Precise identification of pests is crucial if subsequent IPM strategies are to build on knowledge from other locations or sources, because pest species or strains can behave differently and there is little use in duplicating what is already known (Irwin 1999). Pest monitoring is critical because pest abundance and timing must be assessed to estimate the economic significance of the pests, and to develop subsequent solution to the problems. Farmer collaborators selected for on-farm experiments can assist with the monitoring.

Impact assessment is also essential to the PIPM process (Norton et al. 2005b). Assessing the economic, health, environmental, and social implications of alternative IPM technologies feeds directly into recommendations for farmers and policy makers.

\section{Technology Development}

IPM technology development by the IPM CRSP has stressed the necessity of a close link between the farmers and the research program, thus the participatory nature of IPM research. A systems approach has been followed integrating information of various types (technical, economic, climatic, biological, etc.) and based on an understanding of pest population dynamics, markets, and policy constraints (Norton et al. 2005c). Developing IPM packages has involved the employment of multidisciplinary and multi-institutional teams, virtually all of the critical stakeholders. Certain crops require more research for tactic development prior to technology transfer. For example, extensive research has been conducted on rice and this information can be readily transferred to farmers where as 


\section{Identify Participants and Initiate PIPM}

Gather

Secondary

Information
Meet with Stakeholders to Identify Sites and Possible Program Focus
Design Participatory Appraisal and Baseline Survey

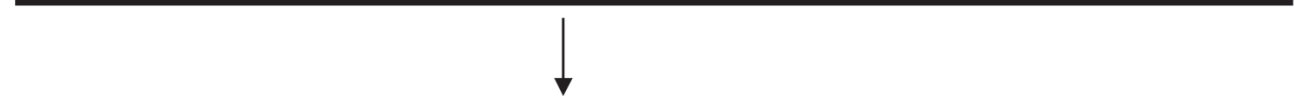

\section{Identify Practices, Problems, and Priorities}

Participatory Appraisal

Workshop to Identify Initial Research Priorities
Conduct Baseline Survey

Crop Pest Monitoring
Develop IPM Tactics and Strategies

Farmer/Scientist Research to Design and Test PIPM Tactics and Systems

Through Laboratory, Greenhouse, and On-farm Trials
Social, Gender, Institutional, and

Policy Analysis
Community Advisory Group: Farmers

Bankers

Marketers/Processors

Extension Agents

Community Leaders
Training, Outreach, Information Exchange

\begin{tabular}{|c|}
\hline Training and \\
Technical \\
Assistance \\
\hline Diffusion of IPM \\
Technologies \\
\hline
\end{tabular}

Information exchange on IPM

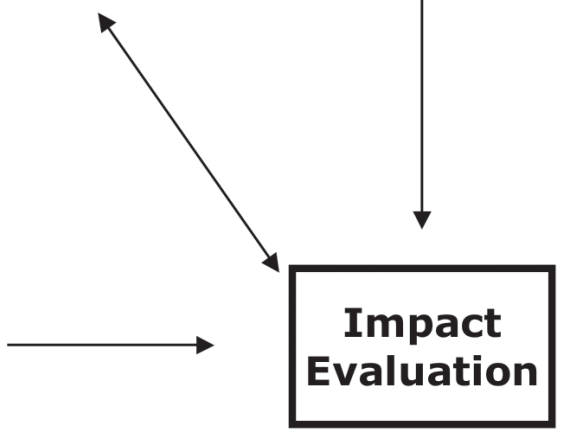


for vegetables and non-traditional fruits much of the needed information to develop control tactics is lacking. Thus, the IPM CRSP with its emphasis on vegetable and fruits has emphasized a strong research program prior to the transfer of technology. The research has been participatory and conducted on farmer's fields and this has shortened the time from research to technology transfer to the farmer. This approach has proven effective at all IPM CRSP sites globally.

\section{Technology Transfer and Adoption}

Participatory IPM research, through its involvement of farmers, marketing agents, and public agencies, is designed to facilitate diffusion of IPM strategies. However, widespread IPM adoption requires careful attention to a host of factors that can spell the difference between a few hundred farmers adopting IPM locally and millions adopting it over a large area. The IPM CRSP has tested several approaches to promote transfer of IPM technology to replace ineffective
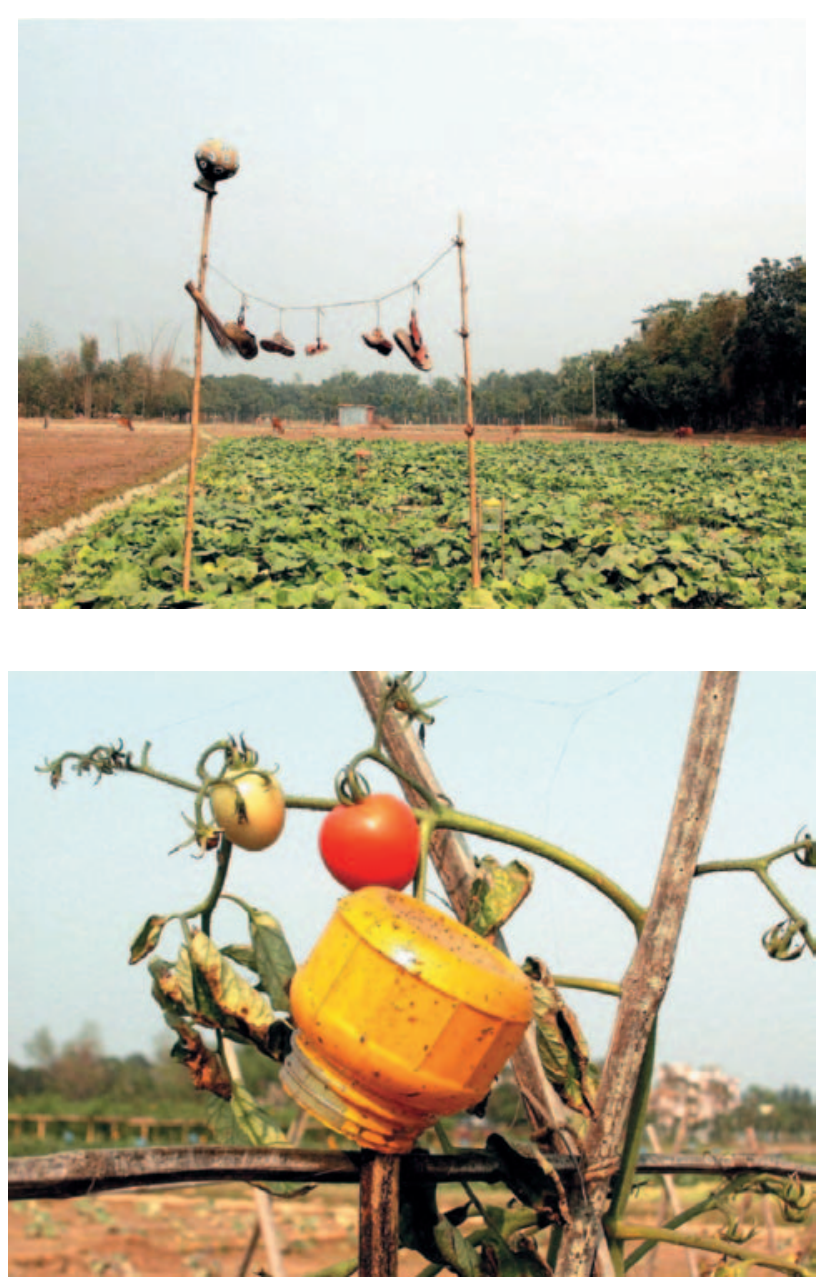

Figure 4. Change in the behavior of Bangladeshi farmers. a) Traditional pest control practices (upper). Shoes, sweep broom and a pot protecting a vegetable field. b)Yellow sticky trap for tomato pest control (lower). traditional pest management practices (Fig. 4a) with more effective modern practices (Fig. 4b).

The ease of transferring technology depends on the environmental sensitivity of the technologies, and on environmental, cultural and other sources of diversity with countries. To speed diffusion of IPM, a multifaceted approach is needed in which all agencies are utilized: traditional public extension agencies, private for profit, and private nonprofitable entities. The "one size fits all" concept does not work in IPM. Instead, a multifaceted approach is needed because of: complexities of IPM programs, vast differences in local public extension capabilities, vast differences in resources, education, and in socio-economics.

The two primary questions that must be addressed in any country hoping to increase the adoption of IPM practices are: which public and private institutional mechanisms can be strengthened and used to speed up the diffusion of IPM knowledge; and what is the optimal mix of approaches for spreading IPM knowledge (Rajotte et al. 2005). Because some IPM knowledge can be conveyed in simple messages while other IPM knowledge requires more complex engagement of farmers, and because of the strengths and weaknesses of various institutional mechanisms, no single approach or institution is likely to be sufficient.

Certain types of private sector involvement can be very helpful in diffusing IPM. For example, cooperatives enable farmers to pool resources and take advantage of technology transfer mechanisms that might otherwise be difficult to access. In the Philippines, the National Onion Growers Cooperative Marketing Association (NOGROCOMA), whose members produce the majority of the onions grown in the country, support their own technology transfer agents and test IPM practices, developed with the assistance of national researchers, on their own demonstration plots and farms. In Guatemala, fruit and vegetable cooperatives help farmers achieve the quality control required for export markets by transferring IPM knowledge to their growers and developing pre-inspection protocols for export crops.

NGOs often make use of a combination of public and private funds to reach small farms and to address management practices ignored by the private sector. Their grassroots contacts tend to be strong. However, their programs may be targeted to small areas, be of short duration, and have few upstream connections to research knowledge. Because each of these three primary institutional mechanisms (public, private, and NGO) has its strengths and weaknesses, and the relative presence of each differs by country, it will often be the case that the combination of the three types of agencies is optimal. A responsibility is placed on any participatory IPM research system to involve all relevant agencies for IPM diffusion.

\section{Regional Spread of IPM Technology}

Regionalization among Asian IPM CRSP sites has been a way to transfer IPM technology from one country to another. Grafting of bacterial wilt resistant rootstocks with scions of popular, but wilt susceptible eggplant varieties, was implemented by the IPM CRSP Bangladesh team (IPM 
CRSProgress Report no. 1, Nov. 1, $2003<$ http:// www.ag.vt.edu/ipmcrsp/IPM\%20CRSProgress.htm>). After dramatically higher yields and profits were obtained, as compared to the farmers' practice of using non-grafted plants, the IPM CRSP Philippines site sent a team member to learn the grafting technique from Bangladeshi scientists. At present, grafted eggplants are also being produced in the Philippines and will have a major impact on the economics of eggplant production there as well. Grafting is a relatively simple procedure, and with training, grafting has the potential to become a cottage industry that provides employment and income. Regionalization of IPM technology will be emphasized in the New IPM CRSP through the development of Regional IPM Centers.

\section{Networking}

We have learned that strong networks are a basic element in a successful Participatory IPM approach (Norton et al. 1999). Participatory IPM involves all stakeholders and the mechanism that provides for the participation of all stakeholders is the networks. The following table (Table 1) lists the agencies involved in technology development and transfer networks at each of the IPM CRSP global sites. This list does not include all of the agencies such as banks, consumer groups, private industry, etc. which are also part of the overall network and have an input into the direction of IPM programs.

The network approach provides a pool of expertise to meet the unique problems existing at each site such as technology development, technology transfer, gender issues, policy instruments, export and quarantine problems, etc. U.S. universities, host country partners, IARCs, NGOs and the private sector working at each site provide the needed range of disciplinary expertise. The makeup of the multiinstitutional teams differs from site to site depending on the constraints. In Jamaica, for example, where hot pepper exports are a problem, the teams include agencies involved in the hot pepper export industry. In Ecuador, linkages with INIAP, FORTIPAPA, PROEXANT, Eco-Salud, Fundacion Maquipucuna, PUCE-IRD-Quito, ESPE-Quito, CIP, FAO, IFPRI, Soils CRSP, Vicosa University, Brazil ESPOCH, MAG-Carchi, PROMSA (World Bank Agricultural Technology and Training Project) and other agencies strengthened the pool of expertise in support of project objectives. The networks have been a major reason for the success of the IPM programs at each regional site.

\section{Government Policy}

Government policies can encourage or discourage the development and adoption of IPM technologies. Thus, policy analysis is often an integral part of a successful IPM program (Norton et al. 2005a). If policies create barriers to IPM adoption, such that there is little economic incentive to adopt, there may be little return to IPM technology development and transfer. The establishment of policies supporting the economic incentives of IPM practices is critical to the success of IPM programs. Among the various types of policies, regulatory mechanisms are most critical to IPM.

Policy analysis with respect to IPM technology transfer is a relatively new science and much more must be done in this area. There is a need for greater interaction between policy makers and economists that are engaged in policy research.

\section{Institutional Capacity Building (Institutionalization)}

The development of strong institutions, that can continue the development and transfer of IPM technology after the IPM CRSP terminates, is a key component of the IPM CRSP approach to the globalization of IPM. The training of scientists (and others) is a key component in the building of IPM capacity within a country and a region. Capacity building involves giving an identity and visibility to IPM programs in each country so that they are appreciated and supported by the countries themselves, and thus, maintained after the IPM CRSP leaves. It involves setting up methods for scientific planning, participatory conduct, review, and evaluation of IPM research and technology transfer activities so that they are recognized as being of high quality and relevant.

Capacity building involves a mix of training approaches ranging from farmer training through the Farmer Field School concept (Quizon et al. 2001) to longterm training of scientists in advanced degree programs. During the first 11 years 93 students received graduate degrees through the IPM CRSP. Training of host country scientists included training in their country, training in another country in the region, or in the U.S. Some students participated in a "sandwich" program where a portion of the program (courses and/or research) was conducted in the host country and the other portion was conducted in the U.S. or at an institution outside the country such as AVRDC. Sandwich programs are less expensive and take scientists out of their systems for a shorter period of time than for example, a $\mathrm{PhD}$ in the U.S. Distance Education should be added to the mix of training methods in the future.

A combination of graduate degree and short-term training has been used to develop capability of the Environmental Toxicology Laboratory in Mali. ETL staff has been trained on site by IPM CRSP chemists and ETL staff has received short-term training at Virginia Tech. Graduate training of ETL staff has been completed at Virginia Tech.

In 1997, Mali could not assure the quality of their vegetable produce for domestic consumption or for export. An Environmental Toxicology Laboratory (ETL) had been built and staffed under a previous project but it was not functioning at a level needed to support either the domestic or the export program. Consequently, the USAID/Mali Mission requested the IPM CRSP to transform the laboratory infrastructure into a functioning unit. In response, the IPM CRSP established an overall laboratory development and staff-training program to develop capacity to monitor pesticide residues. The training has led to sustainable 
Table 1. Partnerships at regional sites (IPM CRSP, 2002-2003).

\begin{tabular}{|c|c|c|c|}
\hline Site & $\begin{array}{l}\text { US university } \\
\text { partners }\end{array}$ & Host country governmental agencies & $\begin{array}{l}\text { IARCs/ NGOs/ } \\
\text { Cooperatives/ } \\
\text { CRSPS }\end{array}$ \\
\hline $\begin{array}{l}\text { Southeast Asia- } \\
\text { Philippines }\end{array}$ & $\begin{array}{l}\text { Ohio State, VA } \\
\text { Tech, Penn State }\end{array}$ & $\begin{array}{l}\text { PhilRice, Institute of Plant Breeding, } \\
\text { National Crop Protection Center } \\
\text { (NCPC), Central Luzon State } \\
\text { University, Leyte State University, } \\
\text { University of the Philippines, Los } \\
\text { Baños (UPLB) }\end{array}$ & $\begin{array}{l}\text { AVRDC, IRRI, } \\
\text { NOGROCOMA }\end{array}$ \\
\hline $\begin{array}{l}\text { South Asia- } \\
\text { Bangladesh }\end{array}$ & $\begin{array}{l}\text { Ohio State, VA } \\
\text { Tech, Penn State, } \\
\text { UC-Davis, Purdue }\end{array}$ & $\begin{array}{l}\text { Bangladesh Agricultural Research } \\
\text { Institute, Bangladesh Rice Research } \\
\text { Institute, Bangabandhu Sheikh } \\
\text { Mujibur Rahman Agricultural } \\
\text { University, NCPC, UPLB }\end{array}$ & AVRDC, IRRI, CARE \\
\hline East Africa- Uganda & $\begin{array}{l}\text { Ohio State, VA } \\
\text { Tech, Fort Valley } \\
\text { State }\end{array}$ & $\begin{array}{l}\text { Makerere University, KARI, } \\
\text { NARO/NARI, SAARI, Pallisa DAO, } \\
\text { Grain Crops Inst., Kumi DAO, } \\
\text { Kaberamaido DAO, Iganga DAO, } \\
\text { Nat. Ag. Advisory Services, Coffee } \\
\text { Res. Inst. (CORI) }\end{array}$ & $\begin{array}{l}\text { CIMMYT, Quality Seed Co., } \\
\text { ICIPE }\end{array}$ \\
\hline West Africa- Mali & $\begin{array}{l}\text { VA Tech, NC } \\
\text { A\&T, Montana } \\
\text { State, UC-Davis, } \\
\text { Purdue }\end{array}$ & $\begin{array}{l}\text { Institut d'Economie Rurale (IER), } \\
\text { OHVN, DGRC, LCV, Univ. De Mali }\end{array}$ & $\begin{array}{l}\text { World Vision, Mali Primeurs } \\
\text { Exporters, Flex Mali } \\
\text { Exporters }\end{array}$ \\
\hline $\begin{array}{l}\text { South America- } \\
\text { Ecuador }\end{array}$ & $\begin{array}{l}\text { VA Tech, Ohio } \\
\text { State, Florida } \\
\text { A\&M, Georgia }\end{array}$ & $\begin{array}{l}\text { INIAP, FORTIPAPA, PROEXANT, } \\
\text { Eco-Salud, Fundacion Maquipucuna, } \\
\text { PUCE-IRD-Quito, ESPE-Quito, } \\
\text { ESPOCH, MAG-Carchi }\end{array}$ & $\begin{array}{l}\text { CIP, FAO, IFPRI, Soils } \\
\text { CRSP, Vicosa Univ., Brazil }\end{array}$ \\
\hline $\begin{array}{l}\text { Central America- } \\
\text { Guatemala/ } \\
\text { Honduras }\end{array}$ & $\begin{array}{l}\text { Purdue, Arizona, } \\
\text { Georgia, Denver }\end{array}$ & $\begin{array}{l}\text { ICADA, ICTA, FHIA, EAP- } \\
\text { Zamorano, Univ.de Vallee } \\
\text { Guatemala, AGEXPRONT }\end{array}$ & $\begin{array}{l}\text { ESTUDIO 1360, APHIS, } \\
\text { FRUTESA, Transcafe }\end{array}$ \\
\hline Caribbean- Jamaica & $\begin{array}{l}\text { Va Tech, Purdue, } \\
\text { Ohio State, Penn } \\
\text { State, UC-Davis, } \\
\text { USDA-ARS }\end{array}$ & $\begin{array}{l}\text { CARDI- Jamaica, St Kitts, St Vincent } \\
\text { and the Grenadines, RADA, MINAG- } \\
\text { Jamaica, Min. of Ag and Fisheries- } \\
\text { Trinidad, Food Storage and } \\
\text { Prevention of Infestation Div. Univ. } \\
\text { of West Indies- Mona }\end{array}$ & $\begin{array}{l}\text { USDA/APHIS, CIPMNET, } \\
\text { FAO }\end{array}$ \\
\hline $\begin{array}{l}\text { East Europe- } \\
\text { Albania }\end{array}$ & $\begin{array}{l}\text { VA Tech, Penn } \\
\text { State, UC- } \\
\text { Riverside, UC- } \\
\text { Kearney Ag. } \\
\text { Center }\end{array}$ & $\begin{array}{l}\text { Plant Protection Institute, Agric. } \\
\text { Univ. of Tirana, Fruit Tree Res. } \\
\text { Institute, MoA Directory of Science } \\
\text { and Extension Service }\end{array}$ & $\begin{array}{l}\text { Albanian Organic Agriculture } \\
\text { Association, Alimentary Oil } \\
\text { Association }\end{array}$ \\
\hline
\end{tabular}

functioning of the pesticide residue laboratory beyond the IPM CRSP project period.

The IPM CRSP has met the need for short-term training of scientists through training periods of 2 weeks to 6 months at U.S. universities, host country universities, on site in the host countries and at the IARCs. Short-term training is used to empower the ability to conduct specific research tasks, thus making scientists proficient in a given technique needed for their research program.

\section{Gender}

The role of women in pest management has implications for IPM (Erbaugh et al. 2003, Bonabana-Wabbi 2003). The IPM CRSP global exipmcrsplperience has taught us how 
to deal with gender issues in transferring IPM technology. In the IPM CRSP projects, a special effort has been made to not only include women farmers wherever possible in all technological transfer activities, including Farmers' Field Schools (FFSs), but also to use women scientists and women extension agents as much as possible. In most locations the farmer is conceived as male, however in practice, a high percentage of women work the land in many countries (see Harris: http://www.ag.vt.edu/ipmcrsp/gender/ gender home.htm). In sub-Saharan Africa, the women carry out most of the agricultural labor. Thus when scientists fail to take women's knowledge into consideration they are losing vital information. Gender differences that affect adoption and impacts of IPM include ownership and control of resources, family-provisioning responsibilities, division of household labor, specialized knowledge of crops, pests and traditional pest management practices, attitudes toward health consequences of pesticide use, and social roles.

The constraints to IPM adoption that are faced by women around the world include both material and ideological factors. It is not unusual for well-meaning members of research teams and agricultural extension programs to expect that even women who work full-time in household agriculture are merely unpaid family labor and that all technical and other relevant decisions are taken by men (Hamilton 2000). The lack of social recognition as farmers has resulted in low levels of formal membership in organizations that offer technical and marketing assistance for the horticultural export crops targeted by the IPM CRSP. Women's participation is of key importance to program success in all phases, from initial reconnaissance and stakeholder identification through iterative planning and implementation, to dissemination of results.

\section{The New IPM CRSP}

In September 2004 U.S. Agency for International Development (USAID) awarded a $\$ 12$ million grant to Virginia Polytechnic Institute and State University (Virginia Tech) to continue leading a consortium of U.S. and international research institutions in implementing a global integrated pest management program through the IPM CRSP. The grant will fund five years of research and education and is renewable for another 5-year period through 2014.

The heart of the New IPM CRSP technical approach is to implement an ecologically-based, participatory IPM (EPIPM) program with a carefully-conceived strategy for local, national, regional, and global diffusion of IPM capacity and knowledge. Broad participation and communication are critical components of the strategy, along with a competitive process and a management plan designed to ensure high quality research and accountability. The approach is structured around competitively designed regional EP-IPM Centers, and global IPM themes.

Regional IPM Centers. Many pest management problems are global in nature, but finding IPM solutions and achieving their adoption depend on attention to local ecological, social, political, economic, institutional, and other differences. Therefore, a successful IPM CRSP program must have, as one cornerstone, a significant presence in major sub-regions of the developing world, a mechanism for spreading IPM knowledge among countries within sub-regions, and links to IPM programs around the world, including programs in more developed countries and international centers. Regional centers will be established by supporting existing national programs in developing increased capabilities to develop IPM and transfer IPM technology to the region. Several components will be required of each regional center: Participation and Linkages. A participatory IPM approach - from farmer to consumer - will be followed to generate and disseminate IPM knowledge that will change behavior of farmers, scientists, extension workers, policy makers and others. The keys to participation are: casting a broad net in making contacts and developing linkages, and following a participatory process that facilitates interactions among scientists, farmers, policy makers, extension workers, agricultural marketing agents, USAID personnel, etc. Each Regional Center will follow a participatory process that is collaborative, evolutionary, and agro-and socio-ecosystem based.

Ecologically Based IPM. Regional IPM Centers will follow an ecologically-based approach centered on four basic tactics: biological control, host plant resistance, resistance management, and habitat management. These tactics will be supported by social, gender, and policy/regulatory analysis to create the necessary environment for IPM adoption and proactively linked to communications, training, and educational programs to accelerate and broaden adoption. Biotechnology. Regional Centers will incorporate biotechnology components where appropriate. The program will interact with on-going national) and international programs that are attempting to generate GMOs for specific pest problems in developing countries. In doing so, it will help host countries to fit biotech solutions into IPM programs designed to minimize resistance problems as well as manage pests other than the ones targeted by the GMOs.

Government Policies and Regulations. Regional Center strategies will involve policy and regulatory development and implementation with respect to pesticides and trade policies (including sanitary and phyto-sanitary issues). Pest management techniques that produce export quality, pesticide free and organic vegetables will be emphasized. Social/Cultural/Economic Analysis. The multidisciplinary EP-IPM approach will not only utilize social/cultural/ economic analysis for addressing policy issues, but also for adoption analysis and impact assessment. IPM adoption will be weak unless social/cultural/economic factors are considered in design and implementation of IPM strategies. Accessibility to resources, land tenure arrangements, gender roles, risk aversion, credit, marketing, and farmer pest perceptions are just some of the important factors.

Gender Analysis. Women are often involved in activities and depend on incomes that are sensitive to IPM interventions. Unless women are involved in incomeenhancing IPM technology development and dissemination, their access to resources and incomes may be affected. 
Therefore each regional IPM program will determine and address the IPM-related production, processing, storage and marketing constraints of women as well as of men.

Systems Modeling and GIS. Systems modeling is undertaken (a) to provide a template for empirical research on crop-pest systems and (b) to provide additional analytical capability on accumulated biological knowledge and data. As a template, mathematical models can organize biological understanding of a system into a framework that can identify the most important gaps in that knowledge and associated data.

Technology Transfer and Communication for Behavioral Change. A major focus of the regional IPM centers will be on: a) leveraging a variety of resources to extend the results of the CRSP and other sources of IPM knowledge, b) researching innovative means of transferring IPM knowledge cost-effectively to the masses, c) maximizing user incentives for IPM adoption, and d) communicating IPM information broadly across countries, regionally, and globally.

Training, Education, and Institutional Capacity Building. Targets of IPM training include growers, extension agents, teachers, government officials, host country and U.S. scientists and students, NGO representatives, marketing cooperatives, and others. Regional programs to increase the IPM capacity of host country and U.S. scientists and extension workers and others will involve both short-term and degree training. Graduate degree training is major component of the IPM CRSP. Each Regional IPM Center program will be asked to identify universities within their regions, which can be matched, with U.S. universities for degree programs. "Sandwich" programs and distance education approaches will be utilized because such programs are less expensive and take scientists out of their systems for a shorter period of time. Training plans will be designed to meet the gaps by discipline that need to be filled to provide sustainable capacity.

Assessment - Each regional IPM program will assess economic (total and poverty), environmental, and gender impacts of its programs. Farm-level as well as market level economic benefits will be calculated for IPM tactics and packages. Farm-level assessment is needed to calculate the profitability of potential IPM recommendations, while market level assessments are needed to provide information on the aggregate net benefits of IPM programs and their distribution. Proposed sites for Regional Centers are: West Africa, Southern Africa, South Asia, Mekong Region, Central America/ Caribbean, Eastern Europe, East Africa, Central Asia, Southeast Asia, and Andean South America.

Global Themes. While many IPM issues are local or regional, a series of issues can be addressed more efficiently globally, perhaps because they involve a problem that is similar around the world or because the issue is method- or service based. The New IPM CRSP will focus its efforts on themes that are expected to provide the most return on investment. These global themes are: Invasive species, insect-transmitted viruses, regional diagnostic labs, information technologies and databases, and impact assessment.
Partners and Collaborating Institutions. Current IPM CRSP partners include the Consortium for International Crop Protection (CICP), Clemson University, Florida A\&M, Michigan State University, North Carolina A\&T, North Carolina State University, Ohio State University, Penn State University, Purdue University and the University of California, Davis. Collaborating institutions include Fort Valley State University, University of California Systemwide Biotechnology Program, and USDA-APHIS-PPQ; the Arcs, The World Vegetable Center-AVRDC, IFPRI, ICARDA, ICIPE, ICRISAT, CIP, IITA, ILRI, and IRRI; the NGOs, CARE/Bangladesh and World Vision; and the private sector, Glades Crop Care, Heinz Seeds, World Cocoa Foundation and Zed, Inc. Additional U.S and host country partners will be added once the winning proposals are selected via the competitive bidding process.

The IPM CRSP has launched invitations to U.S. universities to submit applications for both the regional IPM and global theme IPM programs. The winning proposals will be announced in August 2005. The IPM CRSP website $<$ http://www.ag.vt.edu/IPMCRSP/index.asp>has a portal for non-U.S. university institutions to express their interest in collaborating with U.S. institutions who are preparing proposals. Collaborators can be any U.S. or host country (non-U.S.) institution such as National Agricultural Research Systems (NARS), universities, NGOs, International Agricultural Research Centers (IARCs) and the private sector in any country.

\section{Acknowledgments}

The author acknowledges the support of the United States Agency for International Development (USAID), which funds the IPM CRSP through Grants No. LAG-G-00-9300053-00 and EPP-A-00-04-00016-00 and the support of the participating U.S. and host country institutions.

\section{Literature Cited}

Bonabana-Wabbi, J. 2003. Assessing factors affecting adoption of agricultural technologies: The case of integrated pest management (IPM) in Kumi district, Eastern Uganda. M.S. thesis, Virginia Tech, Blacksburg, VA, pp. 146.

Erbaugh, J., M. Amoral, S. Kyamanywa, \& E. Adipala. 2003. The role of women in pest management decision making in Eastern Uganda. J. Intl. Agric.and Ext. Educ.10-3.

Hamilton, S. 2000. The myth of the masculine market: Gender and agricultural commercialization in the Ecuadorian Andes, p. 65-87. In Anita Spring (ed.), Commercial ventures and women farmers: Increasing food security in developing countries. Boulder, CO, Lynne Reinner Publishers.

IPM CRSProgress Report no. 1, 2003. <http:// www.ag.vt.edu/ipmcrsp/IPM\%20CRSProgress.htm>. 
IPM CRSP, Virginia Tech, Blacksburg, VA. Nov. 1, 2003.

Irwin, M.E. 1999. Implications of movement in developing and deploying pest management strategies. Agric. Forest Meteor. 97: 235-248.

Litsinger, J., G.W. Norton \& V. Gapud. 1995. Participatory appraisal for IPM research planning in the Philippines. IPM CRSP Working paper 95-1 Virginia Tech, September.

Norton, G.W., E.A. Heinrichs, G.C. Luther \& M. E. Irwin. 2005a. Globalizing integrated pest management: A participatory process. Ames, Iowa, USA, Ames, Iowa, USA, Blackwell Publishing Professional, 338p.

Norton, G.W., E.G. Rajotte \& V. Gapud. 1999. Participatory research in integrated pest management: Lessons from the IPM CRSP. Agric. Human Values 16: 431-439.

Norton, G.W., J. Tjornhorn, D. Bosch, J. Ogrodowczyk, C. Edwards, T. Yamagiwa \& V. Gapud. 2005c. Pesticide and IPM policy analysis, p.191-210 In G.W. Norton, E.A. Heinrichs, G.C. Luther \& M. E. Irwin, Globalizing integrated pest management: A Participatory Process. Ames, Blackwell Publishing
Professional, 338p.

Norton, G.W., K. Moore, D. Quishpe, V. Barrera, T. Debass, S. Moyo \& D.B. Taylor. 2005b. Evaluating socio-economic impacts of IPM, p.225-244. In G.W. Norton, E.A. Heinrichs, G.C. Luther \& M. E. Irwin, Globalizing integrated pest management: A Participatory Process. Ames, Blackwell Publishing Professional, 338p.

Quizon, J., G. Feder \& R. Murgai. 2001. A note on the sustainability of the farmer field school approach to agricultural extension. J. Int. Agric. Ext. Edu. 8: 13-24.

Rajottte, E.G., G.W. Norton, G.C. Luther, V. Barrera \& K.L. Heong. 2005. IPM transfer and adoption, p.143157. In G.W. Norton, E.A. Heinrichs, G.C. Luther \& M. E. Irwin, Globalizing integrated pest management: A Participatory Process. Ames, Blackwell Publishing Professional, 338p.

Weller, S.C., G.E. Sanchez, C.R. Edwards \& G.H. Sullivan. 2002. IPM CRSP success in NTAE crops leads to sustainable trade for developing countries. Sust. Dev. Int. 5: 135-138.

Received 22/III/05. 